\title{
Experimental Study of Factors that Affect Iron and Manganese Removal in Slow Sand Filters and Identification of Responsible Microbial Species
}

\author{
Neslihan Manav Demir* \\ Yıldız Technical University, Faculty of Civil Engineering, Environmental Engineering Department, \\ 34220, Esenler, Istanbul, Turkey \\ Received: 18 February 2016 \\ Accepted: 12 April 2016
}

\begin{abstract}
This paper presents the results of DNA-based molecular analyses of the microbial community responsible for biological iron (Fe) and manganese (Mn) removal in slow sand filters (SSF). A lab-scale SSF was operated in 55-day sets under different operating conditions in order to evaluate long-term performance of the filter. The concentrations of Fe and $\mathrm{Mn}$ in synthetic feed water were increased from $1 \mathrm{mg} / \mathrm{L}$ to $2 \mathrm{mg} / \mathrm{L}$ at two different filtration rates $(0.1$ and $0.3 \mathrm{~m} / \mathrm{h})$. Daily samples were taken from influent and effluent for turbidity and Fe-Mn concentration measurements. 90-95\% removal efficiencies were achieved with very low effluent concentrations. PCR-DGGE analyses were performed on samples, and Gallionella, Leptothrix, Crenothrix, and Hyphomicrobium were identified as the main microbial strains responsible for iron and manganese oxidation in SSF. Results also revealed that microbial activity was the main mechanism for Fe and $\mathrm{Mn}$ removal in the early stages of operation.
\end{abstract}

Keywords: slow sand filter, filtration rate, iron-manganese removal, microbial community

\section{Introduction}

Groundwater supplies are always rich in iron $(\mathrm{Fe})$ and manganese $(\mathrm{Mn})$ content, while surface waters exhibit high concentrations for only certain periods of the year. The presence of $\mathrm{Fe}$ and $\mathrm{Mn}$ in high concentrations is undesired in drinking water as these metals are wellknown contributors to color and turbidity. Iron causes staining of clothes and dishes in washing machines. Besides, high concentrations of iron favor bacterial

*e-mail: nmanav@yildiz.edu.tr growth in water transmission and distribution systems. For these reasons, limit values for $\mathrm{Fe}$ and $\mathrm{Mn}$ have been set in drinking water standards throughout the world. World Health Organization (WHO) standards set the iron limit value as $0.3 \mathrm{mg} / \mathrm{L}$, while the limit value is set as $0.2 \mathrm{mg} / \mathrm{L}$ in European and Turkish standards.

Various physical, chemical, and biological processes are employed to reduce $\mathrm{Fe}$ concentrations in drinking water. Aeration and sand filtration are one of the main alternatives preferred for this purpose [1]. Research papers also report the use of membrane filtration systems such as reverse osmosis and nanofiltration for iron and manganese removal $[2,3]$. 
Sand filtration is the oldest and the most reliable process for removing suspended particles as well as ions, micro-pollutants, organic matter, and microorganisms, including pathogens $[4,5]$. The main mechanism of the filtration process can be described as the removal of suspended particles from water by passing it through a porous medium.

Cakmakci et al. [1] listed the main factors affecting Fe removal in the filtration process as dissolved oxygen concentration, alkalinity and $\mathrm{pH}$ of the feed water, oxidation rate in the filter, size distribution and porosity of the filter medium, bed depth, and hydraulic loading.

A slow sand filter (SSF) could be a feasible water treatment option for small communities [6] through their advantages including simple construction and low initial investment cost [7], easy operation and maintenance, and low operating costs by means of lower chemical and energy requirements [8-10]. Besides, SSF requires less area compared to uncontrolled or natural biofiltration processes [11].

Slow sand filtration is commonly used in order to remove various contaminants from water [7]. Although heavy metal and nutrient removal efficiencies are low [12], Schijven [13] reported that suspended solids (SS), turbidity, biochemical oxygen demand (BOI), and fecal coliforms are effectively removed by slow sand filtration.

The schmutzdecke layer is one of the most important factors affecting filtration performance [14]. In contrast to being the major contributor to filter head loss, maturated schmutzdecke improves treatment performance [12]. Corral et al. [15] reported that schmutzdecke is reformed in three days after cleaning the filter bed. Visscher [16] (p. 8) showed that biological activity and other treatment mechanisms in SSF are dominant within the upper 0.4 $\mathrm{m}$ of the filter bed. As filtration continues, the biological agents such as mosses, algae, bacteria, and zooplanktons can penetrate into the sand layer and reach the bottom of the filter bed [17]. Activity of aerobic bacteria depends both on filter bed depth and treatment efficiency [18]. According to Mauclaire et al. [19], microbial activity is the main reason for clogged filters.

This paper presents the results of a research project that focuses on investigating the applicability of slow sand filters for iron and manganese removal in small communities as well as on the identification of a responsible microbial community. A lab-scale SSF was operated under different operating conditions in order to evaluate the relationship between head loss and filter performance. Microbial strains responsible for iron and manganese oxidation were identified using the samples taken from various depths of the filter bed. The relationship between microbial species and filter performance was also discussed.

\section{Materials and Methods}

\section{Experimental Setup}

A lab-scale slow sand filter system consisting of two $40 \mathrm{~cm} \times 60 \mathrm{~cm}$ Plexiglass units was used. Water coming from the synthetic water chamber was supplied to each filter unit at constant rate through separate tubes. The tubes enter the filter units below the water surface. The filtration rate was regulated by a flow-control valve on 8-mm-diameter effluent tubes. Fig. 1 shows the general layout of the system, including the details of nozzles and laterals.

The underdrain system was made up of 10 uniform discharge laterals with dimensions of $56 \mathrm{~cm} \times 3.4 \mathrm{~cm}$. The height of the underdrain was $2.5 \mathrm{~cm}$. Plexiglass nozzles were used above the underdrain system to support the filter medium. 200-mesh stainless steel gauze was laid on

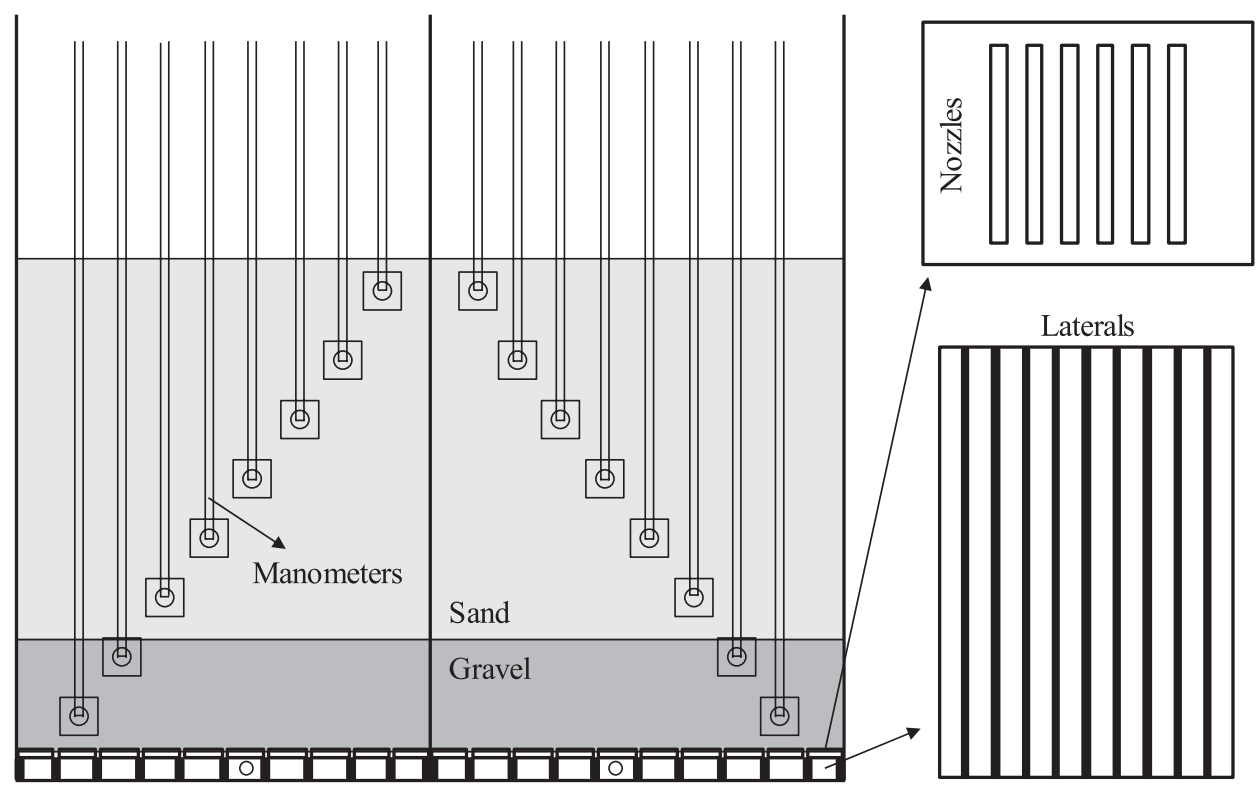

Fig. 1. Lab-scale slow sand filter system. 
nozzles in order to prevent the loss of sand. Both of the filter units were equipped with manometers at 51, 44, 38, $32,26,20,14$, and $8 \mathrm{~cm}$ filter depths.

The depth of sand layer was $37.5 \mathrm{~cm}$, and was laid over the gravel layer, which is $12.5 \mathrm{~cm}$ in depth. The effective size of the silica sand was $0.1 \mathrm{~mm}$. In order to prevent solids accumulating and clogging, influent tubes were removed periodically and cleaned by flushing weak acid solution followed by rinsing with distilled water.

\section{Water Characterization}

Synthetic feed water with 1 and $2 \mathrm{mg} / \mathrm{L}$ of Fe and $\mathrm{Mn}$ concentrations was prepared and supplied to the filters at various flowrates to simulate different operating conditions in SSF. These operating conditions were named SSF1 $(1 \mathrm{mg} / \mathrm{L}$ iron-manganese at $0.1 \mathrm{~m} / \mathrm{h})$, SSF2 $(2 \mathrm{mg} / \mathrm{L}$ ironmanganese at $0.1 \mathrm{~m} / \mathrm{h}), \mathrm{SSF} 3(1 \mathrm{mg} / \mathrm{L}$ iron-manganese at $0.3 \mathrm{~m} / \mathrm{h}$ ), and SSF4 (2 mg/L iron-manganese at $0.3 \mathrm{~m} / \mathrm{h}$ ). Characteristics of feed water are given in Table 1.

\section{Analytical Methods}

Daily samples were taken from influent and effluent of the filter. Total iron and manganese (soluble and insoluble) concentrations were measured by atomic absorption spectroscopy (Perkin Elmer Aanalyst 400) after the samples were prepared by acid digestion (Berghof Products + Instruments GmbH). A WTW Turb 550 IR turbidimeter was used for turbidity measurements. Temperature and $\mathrm{pH}$ were measured using a WTW Multi 340i pH meter. Head loss measurements were performed by Plexiglass manometer tubes with $6 \mathrm{~mm}$ inner diameter (Fig. 1).

\section{Microbial Analyses}

An MN NucleoSpin soil DNA isolation kit (MachereyNagel GmbH \& Co. KG) was used for isolating DNA in samples taken from a slow sand filter. To obtain the mixed community DNAs for DGGE analysis, DNA extracted from samples was used for PCR amplification (initial denaturation for $5 \mathrm{~min}$ at $95^{\circ} \mathrm{C}, 31$ cycles of denaturation for $30 \mathrm{sec}$ at $94^{\circ} \mathrm{C}$, annealing for $1 \mathrm{~min}$ at $50^{\circ} \mathrm{C}$, and extension for $2 \mathrm{~min}$ at $72^{\circ} \mathrm{C}$, with a final extension for 10 min at $72^{\circ} \mathrm{C}$ ) with a BIO-RAD Mycycler Thermal Cycler System. Universal GC-357F (5'-CGC CCG CCG CGC GCG GCG GGC GGG GCG GGG GCA CGG GGG GCC TAC GGG AGG CAG CAG-3') primer, which contains a GC-rich clamp, and 518R (5'-ATT ACC GCG GCT GCT GG-3') primer were used. These primers are suitable for most Bacteria, Archaea and Eucarya.

Each PCR reaction mixture was prepared with a total volume of $50 \mu \mathrm{L}$ containing $3 \mu \mathrm{L}$ of DNA extract, $0.25 \mu \mathrm{L}$ of $100 \mu \mathrm{mol} / \mathrm{L}$ primers, $5 \mu \mathrm{L}$ combination of $10 \mathrm{x}$ reaction buffer (TriseHCl, pH 8.8), $0.125 \mu \mathrm{L}$ of $40 \mathrm{mmol} / \mathrm{L} \mathrm{dNTPs}$, $0.6 \mu \mathrm{L}$ of $5 \mathrm{U} / \mu \mathrm{L}$ Taq DNA Polymerase (BioLabs Inc.), $2 \mu \mathrm{L}$ of $20 \mathrm{mg} / \mathrm{mL}$ bovine serum albumin, and $38.78 \mu \mathrm{L}$ sterile purified water.

The profiles of the PCR-amplified DNA were obtained by denaturing gradient gel electrophoresis analysis (DGGE), which was performed using $8 \%$ polyacrylamide gels (ratio of acrylamide to bisacrylamide, 37.1:1) with denaturing gradient from 30 to $70 \%$ (100\% denaturing solution contains $7 \mathrm{M}$ urea and $40 \%$ formamide) in 1xTAE at $60^{\circ} \mathrm{C}$ and 60 volts for $30 \mathrm{~min}$, which is followed by $60^{\circ} \mathrm{C}$ at 100 volts for 22 hours. The Dcode mutation detection system (Bio-Rad, USA) was used for this purpose. The gel was stained with Sybr-Gold (1,000 x concentration) for $30 \mathrm{~min}$ and visualized on a UV transilluminator. DGGE bands were excised, re-suspended in $20 \mu \mathrm{L}$ of DNase/ RNase-free distilled water, and stored at $4^{\circ} \mathrm{C}$ overnight. An aliquot of supernatant was used for PCR re-amplification by the same PCR protocol except that primers without GC-clamp were used. A nucleic acid extraction kit (GF-1) was used to purify the re-amplified PCR products, after which electrophoresis was performed for assessing the quality of the purification process. Re-amplified and purified PCR products were used for sequencing, and the sequences obtained were compared with public DNA database sequences using the BLAST software (www. ncbi.nlm.nih.gov/blast/).

Table 1. Characteristics of synthetic water.

\begin{tabular}{|c|c|c|c|c|c|c|c|c|c|c|c|c|}
\hline & \multicolumn{3}{|c|}{ SSF1 } & \multicolumn{3}{|c|}{ SSF2 } & \multicolumn{3}{|c|}{ SSF3 } & \multicolumn{3}{|c|}{ SSF4 } \\
\hline & \multirow{2}{*}{$\begin{array}{c}\text { Turbidity } \\
\text { NTU }\end{array}$} & $\mathrm{Fe}$ & $\mathrm{Mn}$ & Turbidity & $\mathrm{Fe}$ & $\mathrm{Mn}$ & \multirow{2}{*}{$\begin{array}{c}\text { Turbidity } \\
\text { NTU }\end{array}$} & $\mathrm{Fe}$ & $\mathrm{Mn}$ & Turbidity & $\mathrm{Fe}$ & $\mathrm{Mn}$ \\
\hline & & \multicolumn{2}{|c|}{$\mathrm{mg} / \mathrm{L}$} & NTU & \multicolumn{2}{|c|}{$\mathrm{mg} / \mathrm{L}$} & & \multicolumn{2}{|c|}{$\mathrm{mg} / \mathrm{L}$} & NTU & \multicolumn{2}{|c|}{$\mathrm{mg} / \mathrm{L}$} \\
\hline Mean $^{\mathrm{a}}$ & 10.1 & 1.04 & 1.05 & 10.2 & 2.11 & 2.04 & 10.4 & 1.03 & 1.09 & 11.0 & 2.06 & 2.02 \\
\hline $\mathrm{STD}^{\mathrm{b}}$ & 1.70 & 0.08 & 0.08 & 1.82 & 0.25 & 0.14 & 1.51 & 0.14 & 0.10 & 1.93 & 0.15 & 0.13 \\
\hline Min. & 7.31 & 0.92 & 0.87 & 7.10 & 1.48 & 1.75 & 7.29 & 0.83 & 0.93 & 7.37 & 1.82 & 1.71 \\
\hline $\mathrm{Q}^{\mathrm{c}}$ & 8.60 & 0.98 & 0.99 & 9.50 & 1.98 & 1.95 & 9.67 & 0.93 & 1.03 & 9.55 & 1.97 & 1.95 \\
\hline $\mathrm{Q}^{\mathrm{d}}$ & 10.0 & 1.03 & 1.04 & 10.0 & 2.10 & 2.03 & 10.0 & 1.01 & 1.08 & 10.8 & 2.04 & 1.99 \\
\hline $\mathrm{Q}^{\mathrm{e}}$ & 11.3 & 1.09 & 1.08 & 11.0 & 2.25 & 2.10 & 11.0 & 1.09 & 1.15 & 12.6 & 2.12 & 2.09 \\
\hline Max. & 13.5 & 1.20 & 1.29 & 14.3 & 2.59 & 2.40 & 14.2 & 1.34 & 1.36 & 15.4 & 2.49 & 2.37 \\
\hline
\end{tabular}

${ }^{\mathrm{a}}$ Average value in 60 samples; ${ }^{\mathrm{b} S T D}$ : Standard deviation in 60 samples; ${ }^{\mathrm{c} Q}$ 1: First quartile; ${ }^{\mathrm{d} Q} \mathrm{2}$ : Median value; ${ }^{\mathrm{e} Q 3}$ : Third quartile. 


\section{Results and Discussion}

Head Loss through Slow Sand Filter

Filter head losses were calculated using daily readings of manometers. The change of head losses in filters with time is shown in Fig. 2 (Figs 2a, 2c, 2e, 2g). These figures clearly show that the filtration rate was a positive contributor to the head loss. Figs $2 \mathrm{a}$ and $2 \mathrm{c}$ show a similar trend. On the other hand, head loss buildup at $0.3 \mathrm{~m} / \mathrm{h}$ was faster as seen in Figs $2 \mathrm{e}$ and $2 \mathrm{~g}$. A closer look at Figs $2 \mathrm{a}$ and $2 \mathrm{c}$ (at $0.1 \mathrm{~m} / \mathrm{h}$ ) reveals that $\mathrm{Fe}$ and Mn concentrations also affect the rate of head loss buildup as higher head losses were observed for $2 \mathrm{mg} / \mathrm{L}$ influent Fe-Mn concentrations. A comparable trend was observed at $0.3 \mathrm{~m} / \mathrm{h}$ (Figs $2 \mathrm{e}$ and $2 \mathrm{~g}$ ) as the rate of head loss buildup was faster for higher influent concentrations.
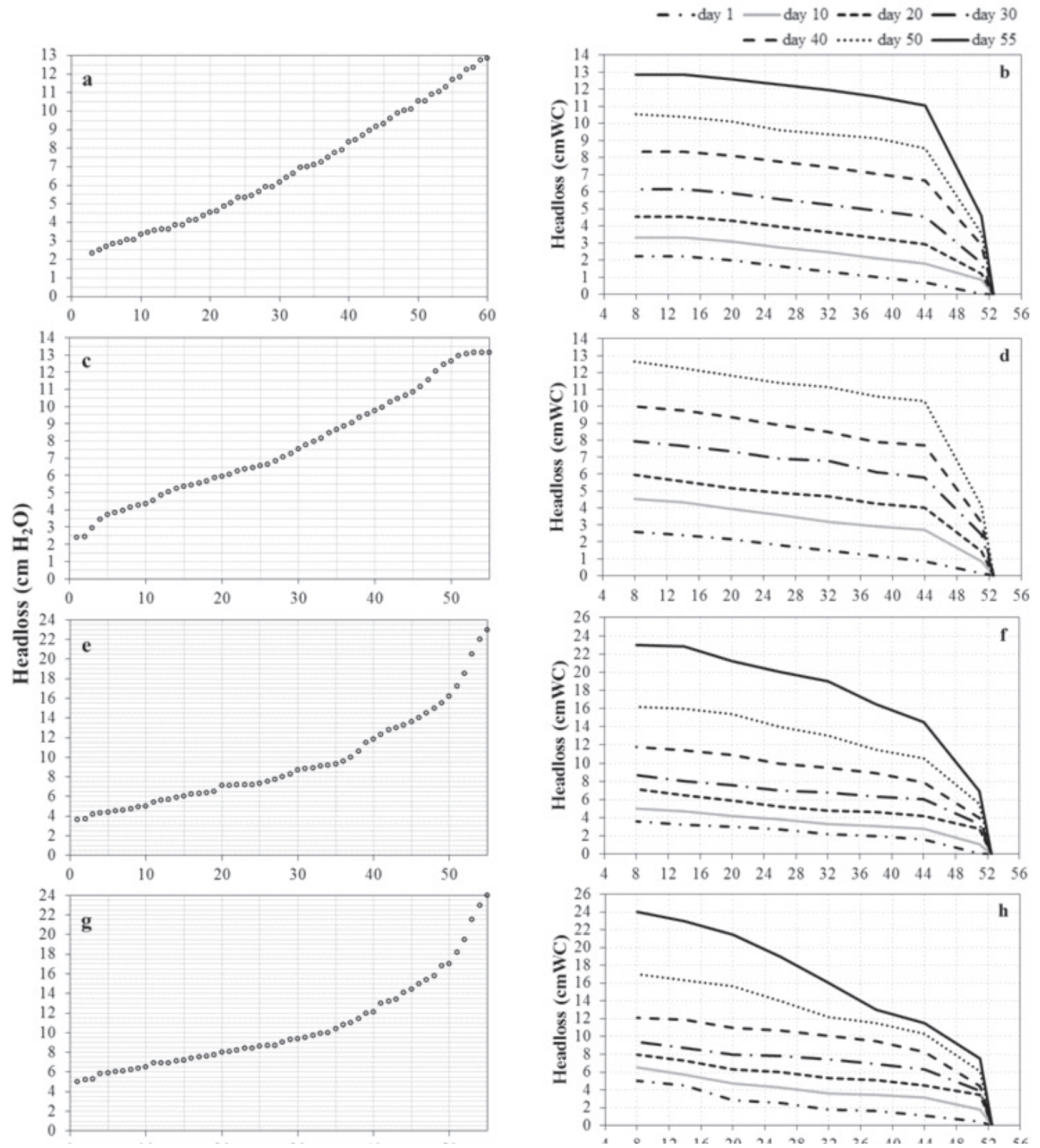

Fig. 2. Measured head losses: a) Filter head loss in SSF1, b) Head losses at pressure taps in SSF1, c) Filter head loss in SSF2, d) Head losses at pressure taps in SSF2, e) Filter head loss in SSF3, f) Head losses at pressure taps in SSF3, g) Filter head loss in SSF4, and h) Head losses at pressure taps in SSF4. 
A linear change of head loss occurs primarily as a result of the passage of water through a porous medium. Thus, Figs $2 \mathrm{~b}, 2 \mathrm{~d}, 2 \mathrm{f}$, and $2 \mathrm{~h}$ could be used as a measure of particle penetration into the sand layer. The linear rise of head loss between $44 \mathrm{~cm}$ and filter bottom points out that the particle penetration into sand layer was negligible at $0.1 \mathrm{~m} / \mathrm{h}$ (Figs $2 \mathrm{~b}$ and $2 \mathrm{~d}$ ). On the other hand, the change of head loss at $0.3 \mathrm{~m} / \mathrm{h}$ (Figs $2 \mathrm{f}$ and $2 \mathrm{~h}$ ) was not linear.
Therefore, particles may have penetrated into the sand layer, or the bottom parts of the sand layer may have compacted at this rate of filtration.

\section{Turbidity Removal}

Effluent turbidities were in the range of $0.97-1.00$ NTU in SSF1, 0.03-0.95 NTU in SSF2, 0.13-0.39 NTU
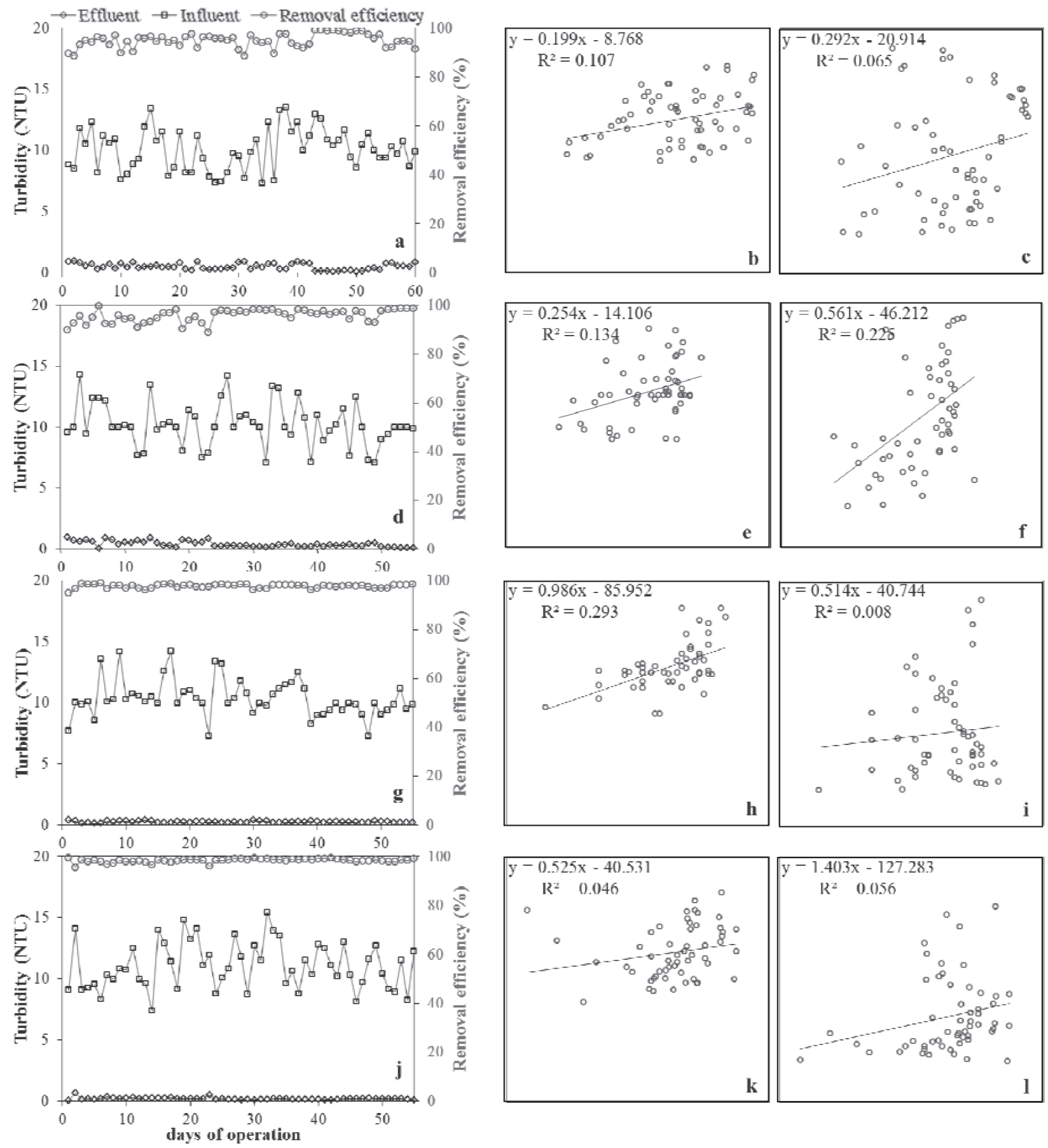

Fig. 3. Turbidity measurement results: a) Influent turbidity (IT), effluent turbidity (ET), and turbidity removal efficiencies (TRE) in SSF1; b) Correlation plot: TRE vs. IT in SSF1; c) Correlation plot: TRE vs. filter head loss $\left(h_{L}\right)$ in SSF1; d) IT, ET, and TRE in SSF2; e) Correlation plot: TRE vs. IT in SSF2; f) Correlation plot: TRE vs. $h_{L}$ in SSF2; g) IT, ET, and TRE in SSF3; h) Correlation plot: TRE vs. IT in SSF3; i) Correlation plot: TRE vs. $h_{L}$ in SSF3; j) IT, ET, and TRE in SSF4; k) Correlation plot: TRE vs. IT in SSF4; and c) Correlation plot: TRE vs. $h_{L}$ in SSF4. 
in SSF3, and 0.06-0.65 NTU in SSF4. Turbidity removal efficiencies were calculated as $94.8 \pm 2.80 \%, 95.9 \pm 2.60 \%$, $97.7 \pm 0.83 \%$, and $98.2 \pm 0.79 \%$, respectively. As seen in Figs. 3a, 3d, 3g, and 3j, turbidity removal efficiency was a function of both filtration rate and influent Fe-Mn concentrations, as it was positively influenced by the rise of these operating parameters. Nonetheless, the effect of influent Fe-Mn concentrations on the turbidity removal efficiency was slight when compared with the strong impact of filtration rate.

Correlation plots were prepared in order to search for a possible relationship between turbidity removal efficiency and influent turbidity as well as head loss (Fig. 3). Figs $3 \mathrm{~b}, 3 \mathrm{e}, 3 \mathrm{~h}$, and $3 \mathrm{k}$ show the change in turbidity removal efficiency with respect to the change in influent turbidity, and Figs. 3c, 3f, 3i, and 31 depict the change in turbidity
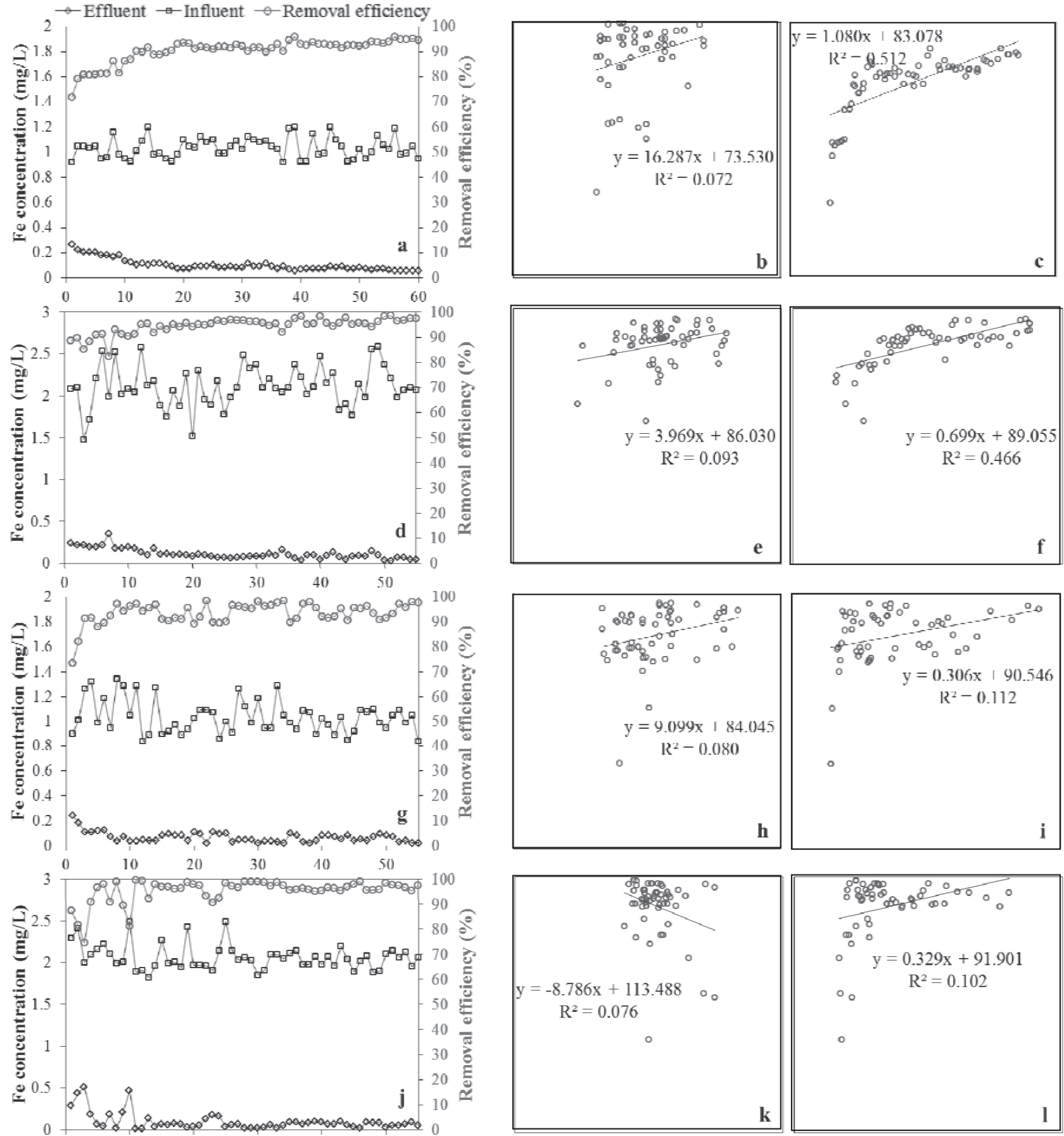

Fig. 4. Iron measurement results: a) Influent iron concentrations (IIC), effluent iron concentrations (EIC), and iron removal efficiencies $(F e R E)$ in SSF1; b) Correlation plot: FeRE vs. IIC in SSF1; c) Correlation plot: FeRE and filter head loss $\left(h_{L}\right)$ in SSF1; d) IIC, EIC, and $F e R E$ in SSF2; e) Correlation plot: FeRE vs. IIC in SSF2; f) Correlation plot: FeRE and $h_{L}$ in SSF2; g) IIC, EIC, and FeRE in SSF3; h) Correlation plot: $F e R E$ vs. IIC in SSF3; i) Correlation plot: $F e R E$ and $h_{L}$ in SSF3; j) IIC, EIC, and FeRE in SSF4; k) Correlation plot: $F e R E$ vs. IIC in SSF4; and (c) Correlation plot: FeRE and $h_{L}$ in SSF4. 
removal efficiency with respect to filter head loss. As seen in Fig. 3b, turbidity removal efficiency in SSF1 was independent from influent turbidity, which was measured between 7.31 and 13.5 NTU during the filter operation. Similarly, a very weak determination coefficient was calculated between turbidity removal efficiency and head loss in SSF1 (Fig. 3c). In SSF2, the influent turbidity was in the range of 7.10-14.3 NTU. Again, the determination coefficients for influent turbidity and head loss were very small (Figs 3d and 3e). The influent turbidity ranged between 7.30 and 14.2 NTU in SSF3, which is coupled with very small correlation coefficients between turbidity removal efficiency and influent turbidity as well as filter head loss (Figs 3h and 3i). Very weak correlations were observed for SSF4 (Figs 3k and 31). The influent turbidity in SSF4 ranged between 7.40 and 15.4 NTU.
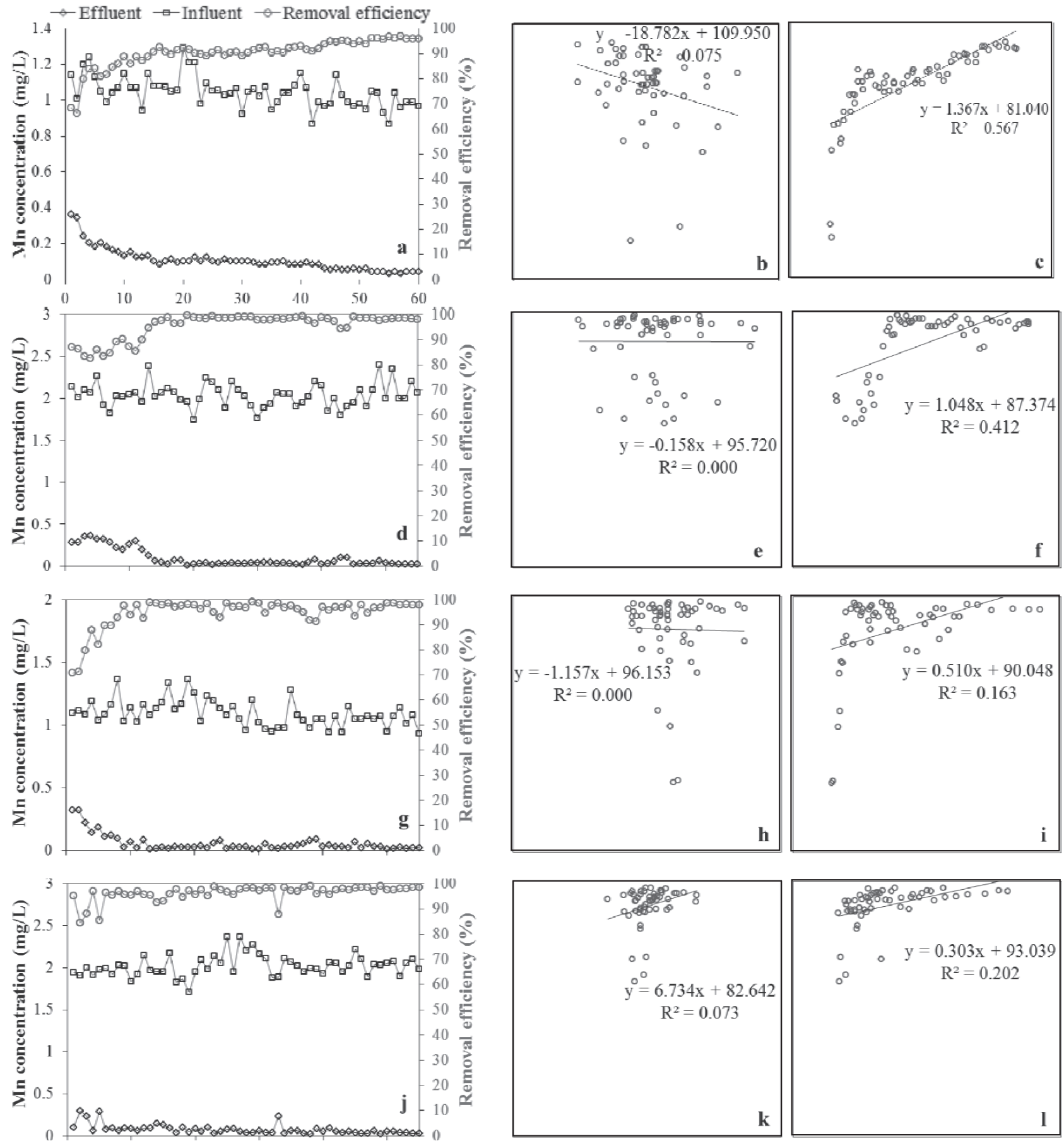

Fig. 5. Manganese measurement results: a) Influent manganese concentrations (IMC), effluent manganese concentrations (EMC), and manganese removal efficiencies (MnRE) in SSF1; b) Correlation plot: MnRE vs. IMC in SSF1; c) Correlation plot: $M n R E$ and filter head loss $\left(h_{L}\right)$ in SSF1; d) $I M C, E M C, M n R E$ in SSF2; e) Correlation plot: $M n R E$ vs. $I M C$ in SSF2; f) Correlation plot: $M n R E$ and $h_{L}$ in SSF2; g) IMC, $E M C, M n R E$ in SSF3; h) Correlation plot: $M n R E$ vs. IMC in SSF3; i) Correlation plot: $M n R E$ and $h_{L}$ in SSF3; j) IMC, EMC, $M n R E$ in SSF4; k) Correlation plot: $M n R E$ vs. IMC in SSF4; and (c) Correlation plot: $M n R E$ and $h_{L}$ in SSF4. 
The determination coefficients calculated for all operating conditions were sufficiently low to conclude that turbidity removal efficiency is a function of neither influent turbidity nor head loss.

\section{Iron Removal}

Changes in influent and effluent iron concentrations are shown in Figs 4a, 4d, 4g, and 4j. Iron removal efficiencies achieved in SSF1, SSF2, SSF3, and SSF4 runs were calculated as $90.4 \pm 4.80 \%, 94.4 \pm 3.20 \%, 93.4 \pm 4.40 \%$, and $95.4 \pm 4.80 \%$ respectively. Iron removal efficiencies showed an increasing trend starting from the beginning of the operation in all runs. Effluent concentrations were sufficiently low and almost constant with small fluctuations.

Influent Fe concentrations and head losses were plotted against $\mathrm{Fe}$ removal efficiencies to reveal any existing relationship (Fig. 4). Calculated values of determination coefficient for influent $\mathrm{Fe}$ concentrations and head loss in SSF1 (Figs $4 \mathrm{~b}$ and $4 \mathrm{c}$ ) pointed out that Fe removal efficiencies shows no considerable tendencies with influent $\mathrm{Fe}$ concentrations, whereas a weak correlation between removal efficiency and head loss exists. In SSF2 (Figs 4h and 4i), SSF3 (Figs 4h and 4i), and SSF4 (Figs $4 \mathrm{k}$ and $4 \mathrm{l}$ ) determination coefficients of similar degrees were observed for influent $\mathrm{Fe}$ concentrations and head loss. Results showed that Fe removal efficiencies were weakly correlated with head loss. Removal efficiency was not influenced by influent Fe concentration. It is worth noting that a rapid increase in Fe removal efficiencies was observed during the early stages of operation and that it was stabilized after a certain level of head loss buildup.

\section{Manganese Removal}

Manganese removal efficiencies were calculated as $90.3 \pm 5.80 \%, 95.4 \pm 5.20 \%, 94.9 \pm 6.14 \%$, and $95.9 \pm 3.50 \%$, respectively, in SSF1, SSF2, SSF3, and SSF4 (Figs 5a, 5d, $5 \mathrm{~g}$, and $5 \mathrm{j}$ ). The effluent concentrations showed decreasing trends starting from the early stages of operation in all runs except SSF4, in which higher fluctuations of effluent manganese concentrations were observed. Results clearly showed that filtration rate contributed positively to manganese removal efficiency. As the influent $\mathrm{Mn}$ concentrations increased, higher Mn removal efficiencies were achieved at $0.1 \mathrm{~m} / \mathrm{h}$. At $0.3 \mathrm{~m} / \mathrm{h}$, however, influent $\mathrm{Mn}$ concentrations slightly influenced Mn removal efficiency.

Mn removal efficiencies were plotted against influent Mn concentrations and head loss in order to track down possible relationships (Fig. 5). Mn removal efficiencies showed trends similar to those observed between $\mathrm{Fe}$ removal efficiencies and head loss (Figs 5c, 5f, 5i, and 51). Regarding the results, reasoning a strong correlation between Mn removal efficiency and influent $\mathrm{Mn}$ concentration is difficult (Figs $5 \mathrm{~b}, 5 \mathrm{e}, 5 \mathrm{~h}$, and $5 \mathrm{k}$ ).

\section{Microbial Community Composition}

The PCR-DGGE method was applied to the samples taken from the slow sand filter in order to investigate the change in microbial communities in the SSF1, SSF2, SSF3, and SSF4 runs. The nucleic acid sequences were compared with public DNA database sequences using BLAST software available at www.ncbi.nlm.nih.gov. Fig. 6 shows the DGGE fingerprints of the amplified partial 16 sRNA genes.

Microbial species identified in samples from the surface as well as at $51 \mathrm{~cm}$ and $44 \mathrm{~cm}$ depths in SSF1 are shown in Table 2. Li et al. [20] reported that Crenothrix sp., which is identified in the first band in $\mathrm{SSF} 1$, is responsible for both $\mathrm{Fe}$ and $\mathrm{Mn}$ removal. The microorganisms in bands 3, 5, 7, and 14 were identified as the members of genus Gallionella, which are reported to be the responsible species for iron oxidation in drinking water treatment [21-23]. The microorganisms identified in bands 4, 5, 10, and 11, Leptothrix sp., are known iron and manganese oxidizers [24]. Besides, Tekerlekopoulou et al. [25] reported that Bacillus sp. and Hyphomicrobium sp., which are identified in bands 13 and 8 , respectively, play a key role in manganese oxidation. Bands 2, 9, 12, and 15 corresponded with several uncultured bacteria encountered in groundwater and water treatment processes.

The number of microbial species decreased toward the depths of the filter bed. In contrast, microbial species other
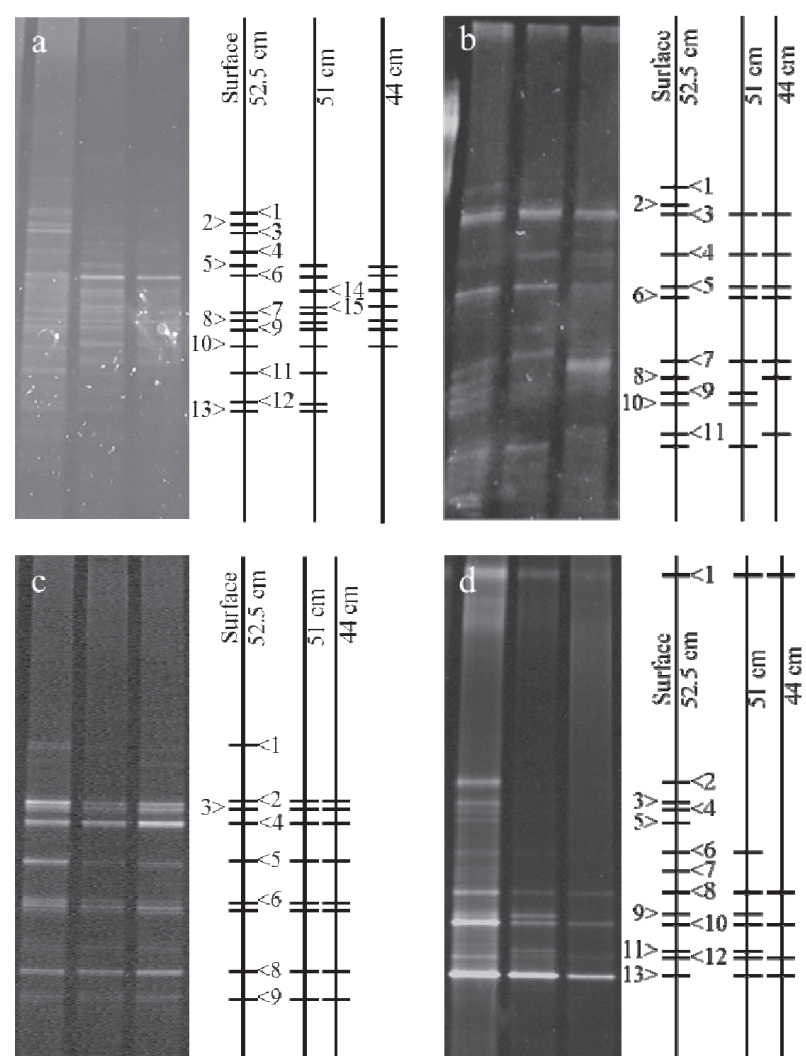

Fig. 6. DGGE fingerprints: a) SSF1, b) SSF2, c) SSF3, and d) SSF4. 
Table 2. Identified microbial species and sequence similarities of excised bands in SSF1.

\begin{tabular}{|c|c|c|c|c|}
\hline $\begin{array}{c}\text { Band / Accession } \\
\text { number }\end{array}$ & $\begin{array}{l}\text { Microorganism name } \\
\text { Isolation source }\end{array}$ & Organism & $\begin{array}{l}\text { Sim. } \\
\%\end{array}$ & Ref. \\
\hline 1 / JN936833 & $\begin{array}{l}\text { uncultured Crenothrix sp. } \\
\text { drinking water sludge }\end{array}$ & Gammaproteobacteria & 100 & {$[26]$} \\
\hline 2 / KF515099 & $\begin{array}{l}\text { uncultured bacterium } \\
\text { drinking water }\end{array}$ & Bacteria & 96 & {$[27]$} \\
\hline 3 / AB252929 & $\begin{array}{l}\text { uncultured Gallionella sp. } \\
\text { iron-oxidazing biofilm }\end{array}$ & Betaproteobacteria & 93 & {$[21]$} \\
\hline 4 / HQ290424 & $\begin{array}{l}\text { Leptothrix ochracea } \\
\text { freshwater iron-seep }\end{array}$ & Betaproteobacteria & 100 & {$[28]$} \\
\hline $5 / \mathrm{Z} 25774$ & Leptothrix discophora & Betaproteobacteria & 100 & [29] \\
\hline 6 / HQ117914 & $\begin{array}{l}\text { Uncultured Gallionella sp. } \\
\text { coastal shallow groundwater }\end{array}$ & Betaproteobacteria & 96 & {$[22]$} \\
\hline 7 / FM878000 & uncultured Gallionella sp. & Betaproteobacteria & 92 & {$[30]$} \\
\hline 8 / GU074283 & $\begin{array}{l}\text { uncultured Hyphomicrobium sp. } \\
\text { freshwater }\end{array}$ & Alphaproteobacteria & 92 & {$[31]$} \\
\hline 9 / GU747260 & $\begin{array}{l}\text { uncultured bacterium } \\
\text { drinking water }\end{array}$ & Bacteria & 99 & {$[32]$} \\
\hline 10 / JQ288616 & $\begin{array}{l}\text { unculture Leptothrix sp. } \\
\text { Full-scale drinking water treatment plant green sand filter media }\end{array}$ & Betaproteobacteria & 100 & {$[33]$} \\
\hline 11 / GU572372 & $\begin{array}{l}\text { uncultured Leptothrix sp. } \\
\text { an Fe-rich seep }\end{array}$ & Betaproteobacteria & 95 & {$[34]$} \\
\hline 12 / LN543247 & $\begin{array}{l}\text { uncultured bacterium } \\
\text { rapid sand filter of groundwater treatment }\end{array}$ & Bacteria & 94 & {$[35]$} \\
\hline 13 / HQ877794 & $\begin{array}{l}\text { uncultured Bacillus sp. } \\
\text { soil }\end{array}$ & Firmicutes & 82 & {$[36]$} \\
\hline 14 / AB670152 & $\begin{array}{l}\text { uncultured Gallionella sp. } \\
\text { an Fe biofilm }\end{array}$ & Betaproteobacteria & 100 & {$[23]$} \\
\hline 15 / KJ670675 & $\begin{array}{c}\text { uncultured bacterium } \\
\text { BioTrap samplers in groundwater monitoring well }\end{array}$ & Bacteria & 96 & {$[37]$} \\
\hline
\end{tabular}

than those in the filter surface were identified at depths of the bed (Bands 14 and 15). The main reason for this could be the penetration of iron and manganese into the filter bed depths. Besides, increasing Fe-Mn removal efficiencies were observed during the first 10 days of operation, while solids buildup at the surface were still low (Figs 4 and 5). It can be concluded that Fe-Mn removal during the maturation period of schmutzdecke was primarily due to biological activity.

Table 3 shows microorganisms identified in samples taken from the surface as well as at $51 \mathrm{~cm}$ and $44 \mathrm{~cm}$ depths in SSF2. Crenothrix sp. was identified in the first band, Gallionella sp. in bands 5 and 12, Leptothrix $s p$. in bands 3, 8, 10, and 11, Bacillus sp. in band 6, and uncultured bacterium in bands 2, 4, 7, and 9. The microbial community structure in SSF2 was very similar to SSF1. Similarly, the number of microbial species decreased toward the depths of the filter bed.

The list of microorganisms identified in samples taken from the surface as well as at $51 \mathrm{~cm}$ and $44 \mathrm{~cm}$ depths of filter bed in SSF3 is shown in Table 4. Bacillus sp. were identified in the first band, Gallionella $s p$. were identified in bands 2, 4, and 8, and Leptothrix sp. were identified in bands 5, 6, and 9. Bands 3 and 7 corresponded to uncultured bacterium. Results showed that the microbial community structure was similar to those in SSF1 and SSF2, with the exception that a considerable decrease in the number of identified species was observed.

Table 5 shows the list of microorganisms identified in samples taken from the surface as well as at $51 \mathrm{~cm}$ and $44 \mathrm{~cm}$ depths of the filter bed in SSF4. Similar to the results from previous runs, Gallionella sp., Leptothrix sp., Hyphomicrobium sp., and uncultured bacterium were identified in SSF4. The disappearance of microbial species toward the depths of the filter bed was the quickest when compared with other runs. Due to quick buildup of accumulated solids at the surface of the filter, the removal rate of iron and manganese in schmutzdecke was high, and probably minor concentrations of these metals were remained below the surface of the filter.

As a result of discussions on slow sand filter operation at various filtration rates and Fe-Mn concentrations, PCRDGGE analyses showed that the microbial community within the filter was dominated by Gallionella, Leptothrix, Crenothrix, and Hyphomicrobium species. Considering the analyses of samples taken from the filter surface 
Table 3. Identified microbial species and sequence similarities of excised bands in SSF2.

\begin{tabular}{|c|c|c|c|c|}
\hline $\begin{array}{c}\text { Band / Accession } \\
\text { number }\end{array}$ & $\begin{array}{l}\text { Microorganism name } \\
\text { Isolation source }\end{array}$ & Organism & Sim. $\%$ & Ref. \\
\hline 1 / JN936833 & $\begin{array}{l}\text { uncultured Crenothrix sp. } \\
\text { drinking water sludge }\end{array}$ & Gammaproteobacteria & 100 & {$[26]$} \\
\hline 2 / KF515099 & $\begin{array}{l}\text { uncultured bacterium } \\
\text { drinking water }\end{array}$ & Bacteria & 96 & {$[27]$} \\
\hline 3 / HQ290424 & $\begin{array}{l}\text { Leptothrix ochracea } \\
\text { freshwater iron-seep }\end{array}$ & Betaproteobacteria & 100 & [28] \\
\hline 4 / KF611948 & $\begin{array}{c}\text { uncultured bacterium } \\
\text { biofilm in drinking water distribution system }\end{array}$ & Bacteria & 94 & [38] \\
\hline $5 /$ AB252929 & $\begin{array}{l}\text { uncultured Gallionella sp. } \\
\text { iron-oxidation biofilm }\end{array}$ & Betaproteobacteria & 93 & [21] \\
\hline 6 / HQ877794 & $\begin{array}{l}\text { uncultured Bacillus sp. } \\
\text { soil }\end{array}$ & Firmicutes & 82 & [36] \\
\hline 7 / GU747260 & $\begin{array}{l}\text { uncultured bacterium } \\
\text { drinking water }\end{array}$ & Bacteria & 99 & {$[32]$} \\
\hline 8 / GU572372 & $\begin{array}{l}\text { uncultured Leptothrix sp. } \\
\text { an Fe-rich seep }\end{array}$ & Betaproteobacteria & 95 & {$[34]$} \\
\hline 9 / LN543247 & $\begin{array}{l}\text { uncultured bacterium } \\
\text { rapid sand filter of groundwater treatment }\end{array}$ & Bacteria & 94 & {$[35]$} \\
\hline 10 / JQ288616 & $\begin{array}{l}\text { Unculture Leptothrix sp. } \\
\text { Full-scale drinkingwater treatment plant green sand } \\
\text { filter media }\end{array}$ & Betaproteobacteria & 100 & [33] \\
\hline $11 /$ Z25774 & Leptothrix discophora & Betaproteobacteria & 100 & [29] \\
\hline 12 / HQ117914 & $\begin{array}{l}\text { uncultured Gallionella sp. } \\
\text { coastal shallows groundwater }\end{array}$ & Betaproteobacteria & 96 & {$[22]$} \\
\hline
\end{tabular}

Table 4. Identified microbial species and sequence similarities of excised bands in SSF3.

\begin{tabular}{|c|c|c|c|c|}
\hline $\begin{array}{c}\text { Band / Accession } \\
\text { number }\end{array}$ & $\begin{array}{l}\text { Microorganism name } \\
\text { Isolation source }\end{array}$ & Organism & Sim. \% & Ref. \\
\hline 1 / HQ877794 & $\begin{array}{l}\text { uncultured Bacillus sp. } \\
\text { soil }\end{array}$ & Firmicutes & 82 & {$[36]$} \\
\hline 2 / AB252929 & $\begin{array}{l}\text { uncultured Gallionella sp. } \\
\text { Iron-oxidation biofilm }\end{array}$ & Betaproteobacteria & 93 & {$[21]$} \\
\hline 2 / KF515099 & $\begin{array}{l}\text { uncultured bacterium } \\
\text { drinking water }\end{array}$ & Bacteria & 96 & {$[32]$} \\
\hline 4 / FM878000 & uncultured Gallionella sp. & Betaproteobacteria & 92 & {$[30]$} \\
\hline 5 / JQ288616 & $\begin{array}{l}\text { Unculture Leptothrix sp. } \\
\text { Full-scale drinkingwater treatment plant green sand filter media }\end{array}$ & Betaproteobacteria & 100 & [33] \\
\hline $6 /$ Z25774 & Leptothrix discophora & Betaproteobacteria & 100 & {$[29]$} \\
\hline 7 / GU747260 & $\begin{array}{l}\text { uncultured bacterium } \\
\text { drinking water }\end{array}$ & Bacteria & 99 & {$[32]$} \\
\hline 8 / HQ117914 & $\begin{array}{l}\text { uncultured Gallionella sp. } \\
\text { coastal shallow ground water }\end{array}$ & Betaproteobacteria & 96 & {$[22]$} \\
\hline 9 / GU572372 & $\begin{array}{l}\text { uncultured Leptothrix sp. } \\
\text { an Fe-rich seep }\end{array}$ & Betaproteobacteria & 95 & [34] \\
\hline
\end{tabular}


Table 5. Identified microbial species and sequence similarities of excised bands in SSF4.

\begin{tabular}{|c|c|c|c|c|}
\hline $\begin{array}{c}\text { Band / Accession } \\
\text { number }\end{array}$ & $\begin{array}{l}\text { Microorganism name } \\
\text { Isolation source }\end{array}$ & Organism & Sim. \% & Ref. \\
\hline $1 /$ JX086255 & $\begin{array}{l}\text { uncultured bacterium } \\
\text { drinking water biofilm }\end{array}$ & Bacteria & 91 & [39] \\
\hline 2 / GU572363 & $\begin{array}{l}\text { uncultured Leptothrix sp. } \\
\text { an Fe-rich seep }\end{array}$ & Betaproteobacteria & 91 & {$[34]$} \\
\hline 3 / GU074283 & $\begin{array}{l}\text { uncultured Hyphomicrobium sp. } \\
\text { freshwater }\end{array}$ & Alphaproteobacteria & 92 & {$[31]$} \\
\hline 4 / LN543247 & $\begin{array}{c}\text { uncultured bacterium } \\
\text { rapid sand filter of groundwater treatment }\end{array}$ & Bacteria & 94 & {$[35]$} \\
\hline 5 / HQ290424 & $\begin{array}{l}\text { Leptothrix ochracea } \\
\text { freshwater iron-seep }\end{array}$ & Betaproteobacteria & 100 & {$[28]$} \\
\hline 2 / KF515099 & $\begin{array}{l}\text { uncultured bacterium } \\
\text { drinking water }\end{array}$ & Bacteria & 96 & {$[32]$} \\
\hline 7 / Z25774 & Leptothrix discophora & Betaproteobacteria & 100 & {$[29]$} \\
\hline 8 / AB252929 & $\begin{array}{l}\text { uncultured Gallionella sp. } \\
\text { iron-oxidation biofilm }\end{array}$ & Betaproteobacteria & 93 & [21] \\
\hline 9/ GU747260 & $\begin{array}{l}\text { uncultured bacterium } \\
\text { drinking water }\end{array}$ & Bacteria & 99 & {$[32]$} \\
\hline 10 / JQ288616 & $\begin{array}{l}\text { Unculture Leptothrix } s p \text {. } \\
\text { Full-scale drinkingwater treatment plant green sand filter media }\end{array}$ & Betaproteobacteria & 100 & {$[33]$} \\
\hline 11 / HQ877794 & $\begin{array}{l}\text { uncultured Bacillus sp. } \\
\text { soil }\end{array}$ & Firmicutes & 82 & {$[36]$} \\
\hline 12 / GU572372 & $\begin{array}{l}\text { uncultured Leptothrix sp. } \\
\text { an Fe-rich seep }\end{array}$ & Betaproteobacteria & 95 & {$[34]$} \\
\hline 13 / FM878000 & uncultured Gallionella sp. & Betaproteobacteria & 92 & {$[30]$} \\
\hline
\end{tabular}

$(52.5 \mathrm{~cm}), 51 \mathrm{~cm}$, and $44 \mathrm{~cm}$, there is enough evidence to conclude that the number of identified species decreased with filter depth.

\section{Conclusions}

The results of a lab-scale experiment performed in this study allowed for the following conclusions to be withdrawn:

- Turbidity removal performance of the slow sand filter does not change with head loss or influent turbidity. Filtration rate is the main operating parameter that affects turbidity removal performance of the slow sand filter.

- Depending on the filtration rate, up to $90-95 \% \mathrm{Fe}$ and Mn removal efficiencies can be achieved by slow sand filtration with effluent concentrations below $0.1 \mathrm{mg} / \mathrm{L}$.

- Iron and manganese removal efficiencies are functions of filtration rate and are independent of filter head loss and influent concentrations.

- Schmutzdecke formation starts immediately after cleaning of the filter and the layer forms within one or two days. During the early stages of operation, biological activity at the surface of the filter is the main mechanism for iron and manganese removal in slow sand filtration.
- Gallionella, Leptothrix, Crenothrix, and Hyphomicrobium species are available within the slow sand filter and are responsible for iron and manganese oxidation. The microbial diversity in depths of the filter is a function of microbial activity at the surface. Reduction of available iron and manganese concentrations through filter diminishes the microbial growth in filter depths.

\section{Acknowledgements}

This research has been supported by The Scientific and Technological Research Council of TURKEY (TUBITAK), grant No. 113 Y392.

\section{References}

1. CAKMAKCI M., KINACI C., BAYRAMOGLU M., YILDIRIM Y. A modeling approach for iron concentration in sand filtration effluent using adaptive neuro-fuzzy model. Expert Syst. Appl. 37, 1369, 2010.

2. MOLINARI R., ARGURIO P., ROMEO L. Studies on interactions between membranes (RO and NF) and pollutants $\left(\mathrm{SiO}_{2}, \mathrm{NO}_{3}^{-}, \mathrm{Mn}^{++}\right.$and humic acid) in water. Desalination 138, 271, 2001.

3. LASTRA A., DANIEL G., JAVIER R., JOSÉ LUIS F., 
SUSANA L., JOSÉ R. Removal of metal complexes by nanofiltration in a TCF pulp mill: technical and economic feasibility. J. Membrane Sci. 242, (1-2), 97, 2004.

4. NOUBACTEP C. Metallic iron for safe drinking water worldwide. Chem. Eng. J. 165, 740, 2010.

5. LEE E., OKI L.R. Slow sand filters effectively reduce Phytophthora after a pathogen switch from Fusarium and a simulated pump failure. Water Res. 47, 5121, 2013.

6. BOURNE D.G., BLAKELEY R.L., RIDDLES P., JONES G.J. Biodegradation of the cyanobacterial toxin microcystin LR in natural water and biologically active slow sand filters. Water Res.40, 1294, 2006.

7. CAMPOS L.C., SU M.F.J., GRAHAM N.J.D., SMITH S.R. Biomass development in slow sand filters. Water Res. 36, 4543, 2002.

8. LANGENBACH K., KUSCHK P., HORN H., KASTNER M. Modeling of slow sand filtration for disinfection of secondary clarifier effluent. Water Res. 44, 159, 2010.

9. BAUER R., DIZER H., GRAEBER I., ROSENWINKEL K-H., LOPEZ-PILA J.M. Removal of bacterial fecal indicators, coliphages and enteric adenoviruses from waters with high fecal pollution by slow sand filtration. Water Res. 45, 439, 2011.

10. Tech Brief. Slow Sand Filtration, A National Drinking Water Clearing House Fact Sheet, 2000; 1-4. Available online: http://www.nesc.wvu.edu/pdf/dw/publications/ontap/2009 tb/slow_sand_filtration_dwfsom40.pdf. Accessed on $1 \overline{4}$ January 2016.

11. ZHENG X., ERNST M., JEKEL M. Pilot-scale investigation on the removal of organic foulants in secondary effluent by slow sand filtration prior to ultrafiltration. Water Res. 44, 3203, 2010.

12. EPA. Storm Water Technology Fact Sheet: Sand Filters, United States Environmental Protection Agency, Office of Water, Washington, D.C. EPA 832-F-99-007, September 1999. Available online: http://nepis.epa.gov/Exe/ZyPDF. cgi/200044AG.PDF?Dockey=200044AG.PDF. Accessed on 14 January 2016.

13. SCHIJVEN J.F., VAN DEN BERG H.H.J.L., COLIN M., DULLEMONT Y., HIJNEN W.A.M., MAGIC-KNEZEV A., OORTHUIZEN W.A., WUBBELS G. A mathematical model for removal of human pathogenic viruses and bacteria by slow sand filtration under variable operational conditions. Water Res. 47, 2592, 2013.

14. ADIN A. Slow granular filtration for water reuse. Wa. Sci. Technol. 3, 123, 2003.

15. CORRAL A.F., YENAL U., STRICKLE R., YAN D., HOLLER E., HILL C., ELA W.P., ARNOLD R.G. Comparison of slow sand filtration and microfiltration as pretreatments for inland desalination via reverse osmosis. Desalination 334, 1, 2014.

16. VISSCHER J.T., PARAMASIVAN R., RAMAN A., HEIJNEN H.A. Slow Sand Filtration for community Water Supply planning, design, construction, operation and maintenance, Technical paper series no.24; Publisher: International Reference Centre for Community Water Supply and Sanitation, Netherland, 8, 1987.

17. GOTTINGER M.A., MCMARTIN D.W., PRICE D., HANSON B. The effectiveness of slow sand filters to treat Canadian rural prairie water. Can. J. Civil Eng. 38, 455, 2011.

18. PETITJEAN A., FORQUET N., WANKO A., LAURENT J., MOLLE P., MOSE' R., SADOWSKI A. Modelling aerobic biodegradation in vertical flow sand filters: Impact of operational considerations on oxygen transfer and bacterial activity. Water Res. 46, 2270, 2012.
19. MAUCLAIRE L., SCHÜRMANN A., THULLNER M., GAMMETER S., ZEYER J. Sand filtration in a water treatment plant: biological parameters responsible for clogging. J. Water Supply Res. T. 53, 93, 2004.

20. LI X., CHU Z., LIU Y., ZHU M., YANG L., ZHANG J. Molecular characterization of microbial populations in full-scale biofilters treating iron, manganese and ammonia containing groundwater in Harbin, China. Bioresource Technol. 147, 234, 2013.

21. SAKURAI K., TAZAKI K., YAMAGUCHI K. Identification of bacteria in an iron-oxidation biofilm at Shibayama lagoon, Ishikawa, Japan. Published Only in Database (2006). Available online: http://www.ncbi.nlm.nih.gov/nuccore/ AB252929. Accessed on 14 January 2016.

22. LIN C.F., LARSEN E.I., NOTHDURFT L.D., SMITH J.J. Neutrophilic, microaerophilic Fe(II)-oxidizing bacteria are ubiquitous in aquatic habitats of a subtropical Australian coastal catchment. Geomicrobiol. J. 29, 76, 2012.

23. MITSUNOBU S., MAKITA H., KIKUCHI S. Biogenic iron oxyhydroxides characterized by directly coupled phylogenetic and chemical speciation. Available online: http://www.ncbi.nlm.nih.gov/nuccore/AB670152. Accessed on 14 January 2016.

24. KATSOYIANNIS I.A., ZOUBOULIS A.I. Biological treatment of $\mathrm{Mn}$ (II) and $\mathrm{Fe}(\mathrm{II})$ containing groundwater: kinetic considerations and product characterization. Water Res. 38, 1922, 2004.

25. TEKERLEKOPOULOU A.G., VASILIADOU I.A., VAYENAS D.V. Biological manganese removal from potable water using trickling filters. Biochem. Eng. J. 38, 292, 2008.

26. MA G.X., PEI H.Y., JI Y. Study on Microbial Community in Drinking Water Sludge by PCR-DGGE. Available online: http://www.ncbi.nlm.nih.gov/nuccore/JN936833. Accessed on 14 January 2016.

27. DAI Y., ZHANG J., XIE S. Bacterial communities in drinking water distribution systems. Available online: http:// www.ncbi.nlm.nih.gov/nuccore/KF515099. Accessed on 14 January 2016.

28. FLEMING E.J., LANGDON A.E., MARTINEZ-GARCIA M., STEPANAUSKAS R., POULTON N.J., MASLAND E.D., EMERSON D. What's new is old: resolving the identity of Leptothrix ochracea using single cell genomics, pyrosequencing and FISH. PLOS ONE 6, e17769, 2011.

29. CORSTJENS P.L.A.M., DE VRIND J.P.M., GOOSEN T., DE VRIND-DE JONG E.W. Identification and Molecular Analysis of the Leptothrix discophora SS-1 mofA Gene, a Gene Putatively Encoding a Manganese Oxidizing Protein with Copper Domains. Geomicrobiol. J. 14, 91, 1997.

30. BLOTHE M., RODEN E.E. Microbial iron redox cycling in a circumneutral-pH groundwater seep. Appl. Environ. Microbiol. 75, 468, 2009.

31. AIZENBERG-GERSHTEIN Y., VAIZEL-OHAYON D., HALPERN M. Structure of bacterial communities in diverse freshwater habitats. Can. J. Microbiol. 58, 326, 2012.

32. KWON S., MOON E., KIM T.S., HONG S., PARK H.D. Pyrosequencing demonstrated complex microbial communities in a membrane filtration system for a drinking water treatment plant. Microbes Environ. 26, 149, 2011.

33. ISLAM A.A., TOBIASO J.E. Release of manganese from groundwater treatment filter media. http://www.ncbi.nlm. nih.gov/nuccore/JQ288616. Accessed on 14 January 2016.

34. JOHNSON K.W., MCDONALD W., CARMICHAEL M.J., ROSE N., PITCHFORD J., WINDELSPECHT M., KARATAN E., BRAUER S.L. Increased abundance of Gallionella spp., Leptothrix spp. and total bacteria 
in response to enhanced $\mathrm{Mn}$ and $\mathrm{Fe}$ concentrations in a disturbed southern Appalachian high elevation wetland. Available online: http://www.ncbi.nlm.nih.gov/nuccore/ GU572372. Accessed on 14 January 2016.

35. GULAY A., TATARI K., MUSOVIC S., MATEIU R.V., ALBRECHTSEN H.J., SMETS B.F. Internal porosity of mineral coating supports microbial activity in rapid sand filters for groundwater treatment. Appl. Environ. Microbiol. 80, 7010, 2014.

36. LI L., YANG W.H., ZHANG Z. Diversity and composition of bacteria related to manganese oxidization through a soil profile using culture-dependent and culture-independent methods. Available online: http://www.ncbi.nlm.nih.gov/ nuccore/HQ877794. Accessed on 14 January 2016.

37. NOUSIAINEN A.O., BJORKLOF K., SAGARKAR
S., NIELSEN J.L., KAPLEY A., JORGENSEN K.S. Bioremediation strategies for removal of residual atrazine in the boreal groundwater zone. Appl. Microbiol. Biotechnol. 99, 10249, 2015.

38. DOUTERELO I., SHARPE R., BOXALL J. Bacterial community dynamics during the early stages of biofilm formation in a chlorinated experimental drinking water distribution system: implications for drinking water discolouration. J. Appl. Microbiol. 117, 286, 2014.

39. REVETTA R.P., GOMEZ-ALVAREZ V., GERKE T.L., CURIOSO C., SANTO DOMINGO J.W., ASHBOLT N.J. Establishment and early succession of bacterial communities in monochloramine-treated drinking water biofilms. FEMS Microbiol. Ecol. 86, 404, 2013. 